\title{
INNOVATIONS IN THE INDUSTRY OF CRYPTOCOINS, GAMES AND STARTUPS
}

\section{Chair: José Dias - CEO Mixmedia - Content Production Director - SET}

This meeting will show how the Forex and Cryptocoins are revolutionizing the global financial ecosystem. How to make money with Cryptocoins. Learn how to lead a Startup to success. And how is the revolution of the Games industry in Brazil and abroad.

- GAMES: LEARN MORE ABOUT THE GAME MARKET IN BRAZIL AND THE WORLD

Speaker: Fernando Chamis - Presidente da ABRAGAMES - Associação Brasileira dos Desenvolvedores de Jogos Digitais

In this presentation, Fernando Chamis, CEO of Webcore Games and President of Abragames (Brazilian Association of Game Developers) shows data, examples, technologies and curiosities about the gaming market in Brazil and in the World.

- HOW TO MAKE A STARTUP A SUCCESS Speaker: Cidinaldo Boschini - CEO | 2C Turnaround Consulting \& Associates One need not necessarily have the solution developed ... There is no business with potential where the market is small ... You can not manage what you do not measure. What is important to make a successful startup?

- CRYPTOCOINS Speaker: Octávio Moura - Trader em CriptoMoeda

Focusing on the Cryptocoins market, this meeting aims to provide participants with a simple and deep understanding of the complex change that has taken place in the global financial ecosystem. It will be addressed issues of collective interest, which aim to show when this movement began, what the reasons, the main consequences and how to take advantage of this new form of financial communication, which has gained supporters every day around the world. 


\section{- FOREX (FOREIGN EXCHANGE) Speaker: William Soares - Trader Forex}

The ease of trading apps enables you to invest even with little experience. Discover one of the markets that can be part of your investment portfolio from now on. FOREX - What is it? How it works? The foreign exchange market, or FOREX "foreign exchange" is the world's largest market in terms of money traded daily, with more than 5 trillion dollars transacted daily. How do you trade FOREX?

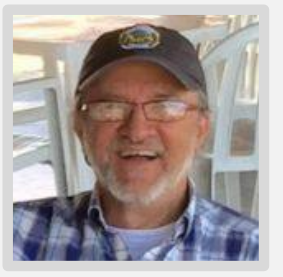

\section{José Dias - CEO Mixmedia - Content Production Director -SET}

He has dedicated himself over the last 40 years to Television Engineering and Production Techniques and to the study into the use of computers to give a more dynamic visual aspect and the sophisticated techniques for generating images and special effects for TV and the cinema. Between 1979 and 1984 he was leader in the development of the Computer Graphics Technology that revolutionized the visual aspects of the Globo Television Network in the 1980s.

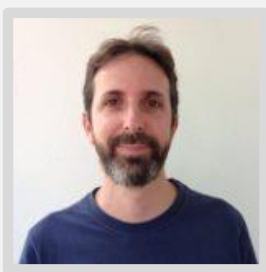

\section{Fernando Chamis - Presidente da ABRAGAMES - Associação Brasileira dos Desenvolvedores de Jogos Digitais}

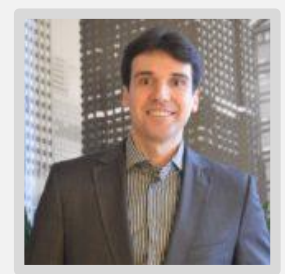

\section{Cidinaldo Boschini - CEO | 2C Turnaround Consulting \& Associates}

Specialist in Turnaround with over 11 years of experience in area. Developed Reorganization projects in more than 80 companies throughout Brazil. Also Angel Investor in technology Startups, Entrepreneur \& Venture Capitalist

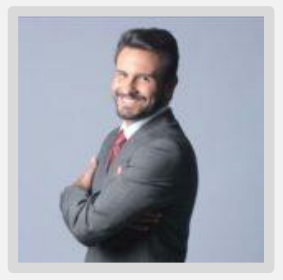

\section{Octávio Moura - Trader em CriptoMoeda}

Graduate in History and Post Graduate in Clinical PsychoanalysisSpeaker and human developer began his first contacts with the market of Cryptocoins in 2011 giving lectures on the subject throughout Brazil.

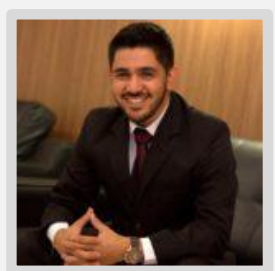

\section{William Soares - Trader Forex}

Technician in Real Estate Transactions, Specialist in Investment Management and Professional Coach. 